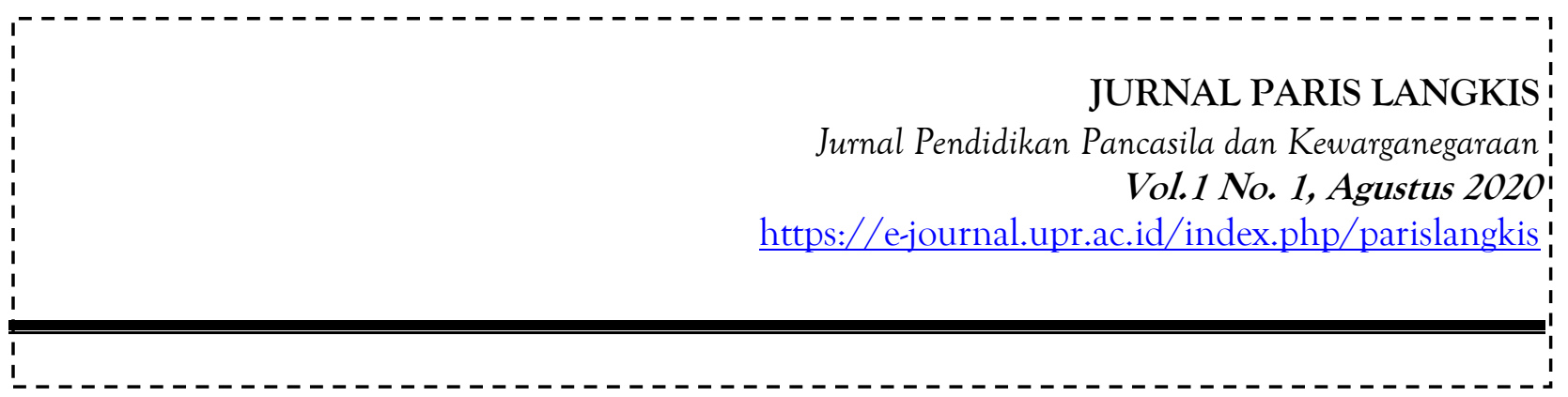

\title{
STUDI TENTANG PERGESERAN MATA PENCAHARIAN MASYRAKAT DI DESA TANGKI DAHUYAN KECAMATAN MANUHINGKABUPATEN GUNUNG MAS
}

\author{
Siska Kristina ${ }^{1}$, Offeny ${ }^{2}$, Triyani ${ }^{3}$. \\ ${ }^{1,2,3}$ Program Studi Pendidikan PPKn, Jurusan Pendidikan Ilmu Pengetahuan Sosial \\ Universitas Palangka Raya \\ e-mail: Siskakristina5@gmail.com¹,offeny.pky58@gmail.com², triyani@fkip.upr.ac.id ${ }^{3}$,
}

\begin{abstract}
Abstrak:
Penelitian ini ingin melihat permasalahan tentang Pergeseran Mata Pencaharian Masyarakat di Desa Tangki Dahuyan Kecamatan Manuhing Kabupaten Gunung Mas”. Tujuannya untuk mengetahui proses Pergeseran Mata Pencaharian Masyarakat di Desa Tangki Dahuyan Kecamatan Manuhing Kabupaten Gunung Mas. Metode penelitian menggunakan metode deskristif kualitatif. Subjek penelitian ini adalah kepala desa, masyarakat Desa Tangki Dahuyan seperti peyedap karet dalam hal yang ditanya sebagai informan tentang pergeseran mata pencaharian masyrakat. Prosedur pegumpulan data menggunakan observasi partisipatif, wawancara mendalam dan dokumentasi sedangkan analisis data meliputi reduksi data, display data, dan verifikasi data dan pemeriksaan keabashan data melalui triangulasi teknik dan triangulasi sumber. Hasil penelitian menunjukan bahwa telah terjadi pergeseran mata pencaharian pada masyarakat Desa Tangki Dahuyan Kecamatan Manuhing Kabupaten Gunung Mas. Proses terjadinya pergeseran mata pencaharian masyarakat dikarenakan adanya faktor ekonomi yang lemah, menurunnya hasil panen petani serta turunnya harga karet yang secara signifikan. Ada beberapa faktor penyebab terjadinya pergeseran mata pencaharian pada masyarakat Desa Tangki Dahuyan yaitu faktor ekonomi yang lemah, pendapatan sebelumnya minim dan rasa ingin punya penghasilan yang lebih baik dari sebelumnya dengan menjadi karyawan di perusahaan kelapa sawit.Dengan menjadi karyawan di perusahaan kelapa sawit pendapatan masyarakat lebih meningkat dibandingkan dengan hasil menyadap karet. Hasil yang dirasakan pada masyarakat dirasa positif karena hasil dari perusahaan yang di dapat digunakan untuk biaya kebutuhan hidup sehari-hari tercukupi serta dapat membiayai pendidikan anak-anaknya. Kemudian masyarakat yang bergeser pekerjaan ke perusahaan kelapa sawit mendapatkan suatu jaminan sosial yaitu berupa Jaminan Sosial Tenaga Kerja dan BPJS Kesehatan.
\end{abstract}

\section{Paris Langkis}

Vol.1 No. 1, Agustus 2020 
Kata Kunci : Pergeseran; Mata Pencaharian; Masyrakat Desa Tangki Dahuyan

\begin{abstract}
.
This study wants to look at the problem of Shifting Community Livelihoods in the Tank of Dahuyan Village, Manuhing District, Gunung Mas Regency. The aim is to find out the process of Shifting Community Livelihoods in the Tank of Dahuyan Village, Manuhing District, Gunung Mas Regency. The research method uses qualitative descriptive method. The subject of this study was the village head, the people of the Tank Village of Dahuyan such as rubber dabblers in terms of being asked as informants about shifting people's livelihoods. Data collection procedures use participatory observation, in-depth interviews and documentation while data analysis includes data reduction, data display, and data verification and checking the accuracy of the data through technical triangulation and source triangulation. The results showed that there was a shift in livelihoods in the community of Dahuyan Tank Village, Manuhing District, Gunung Mas Regency. The process of shifting people's livelihoods is due to a weak economic factor, a decline in farmers' yields and a significant decline in rubber prices. There are several factors causing the shift in livelihoods in the Tank Dahuyan Village community, which are weak economic factors, low prior income and a sense of wanting to have a better income than before by becoming an employee in an oil palm company. By becoming an employee in an oil palm company the community income is more increased compared to the results of rubber tapping. The results felt in the community are felt positive because the results of the company that can be used for the cost of daily needs are sufficient and can pay for their children's education. Then people who shift jobs to oil palm companies get a social security in the form of Workers' Social Security and Health BPJS.
\end{abstract}

Keywords: Shift; Livelihood; Dahuyan Tank Village Community

\title{
A. PENDAHULUAN
}

Pergeseran atau perubahan bisa terjadi setiap saat, dan merupakan proses yang dinamik serta tidak dapat dielakkan. Berubah berarti beranjak dari keadaan yang semula.Tanpa berubah tidak ada pertumbuhan dan tidak ada dorongan.Namun dengan berubah terjadi ketakutan, kebingungan dan kegagalan dan kegembiraan. Setiap orang dapat memberikan perubahan pada orang lain. Merubah orang lain bisa bersifat implisit dan eksplisit atau bersifat tertutup dan terbuka. Disisi lain yang dominan dalam perubahan itu sendiri, tidak boleh dipungkiri karena adanya penemuan baru (invention), pertumbuhan penduduk dan kebudayaan (culture) aspirasi seorang individu atau kelompok dalam melaksanakan perubahan sangat dipengaruhi oleh inovasi dan adaptasi dari setiap teknologi yang baru muncul, atau nampak ditengah-tengah masyarakat, baik teknologi yang berasal dari dalam (intern) maupun luar (ekstren) negeri(Sutyitno, 2012).Fenomena ini menggambarkan bahwa betapa pentingnya inovasi bagi kemajuan dan perubahan dalam suatu masyarakat, sehingga pada akhirnya dapat dijadikan sebagai bagian dari peradaban masyarakat salah satunya yaitu bergesernya mata pencaharian dengan berkembangnya pertumbuhan industri perkebunan sawit sehingga tidak sedikit orang mencoba merubah sistem mata pencahariannya.

Sayur merupakan salah satu komoditas yang paling pokok dalam sektor ekonomi dan termasuk komoditas penting disektor perkebunan setelah kelapa sawit. Perubahan bisa terjadi setiap saat, dan merupakan proses yang dinamik serta tidak dapat dielakkan. Berubah berarti beranjak dari keadaan yang semula.Tanpa berubah tidak ada pertumbuhan dan tidak ada dorongan.Namun dengan berubah terjadi ketakutan, kebingungan dan kegagalan dan

\section{Paris Langkis}

Vol.1 No. 1, Agustus 2020 
kegembiraan. Setiap orang dapat memberikan perubahan pada orang lain. Merubah orang lain bisa bersifat implisit dan eksplisit atau bersifat tertutup dan terbuka. Disisi lain yang dominan dalam perubahan itu sendiri, tidak boleh dipungkiri karena adanya penemuan baru (invention), pertumbuhan penduduk dan kebudayaan (culture).

Peluang masyarakat Indonesia untuk memperoleh mata pencaharian baik dalam bidang pertanian maupun non-pertanian terkait erat dengan persoalan ketersediaan sumber daya, beragam pelaku dan kepentingan terhadap sumber daya, aturan formal dan informal yang diberlakukan, serta hubungan sosial ekonomi dan budaya.Aspek- aspek tersebut secara langsung atau tidak langsung saling pengaruh mempengaruhi pilihan bentuk penghidupan masyarakat, karena menentukan akses dan kontrol masyarakat atas sumber penghidupan, mekanismemekanisme pertukaran yang harus ditempuh, serta syarat bagi keberlangsungan untuk mempertahankan produksi atas sumber penghidupan tersebut.

\section{B. KAJIAN TEORI}

Masyarakat selalu mengalami perkembangan dan perubahan kendati pun hanya sedikit.Daya gerak perubahan masyarakat dapat berasal dari luar masyarakat atau manusia, tapi juga dapat bersumber dari dalam kesadaran berpikir manusia atau malah sintesa antara keduanya.Pandangan seseorang terhadap suatu realitas mendasari seseorang untuk menentukan langkah kerja selanjutnya.Pergseran mata pencaharian adalah salah satu contoh fenomena perubahan yang terjadi dalam masyarakat(Rolina, 2013).

Mata pencaharian merupakan pekerjaan pokok yang dilakukan oleh masyarakat.Setiap individu dalam masyarakat harus mempunyai pekerjaan pokok untuk menopang kebutuhan ekonomi mereka.Dalam perkembangannya mata pencaharian seseorang sering berubah, yang biasa disebut pergeseran mata pencaharian atau transformasi pekerjaan(Angkasawati, 2015).

Pergeseran mata pencaharian atau biasa disebut transformasi pekerjaan dalam tulisan ini dilihat dari unsur-unsur pokok yang dipaparkan dalam penelitian-penelitian sebelumnya.Unsurunsur pokok yang terdapat didalamnya adalah pertama, transformasi pekerjaan biasanya ditandai dengan adanya perubahan orientasi masyarakat mengenai mata pencaharian(Ismanto, Huda, \& Maulida, 2013). Pergeseran orientasi mata pencaharian disini diartikan sebagai perubahan pemikiran masyarakat yang akan menentukan dan mempengaruhi tindakannya di kemudian hari, dalam hal mata pencaharian atau pekerjaan pokok. Kedua,transformasi pekerjaan biasa terjadi karena ada faktor-faktor internal (semisal minat, bakat, dan kesempatan), eksternal (kondisi lingungan sosial-ekologis) maupun kombinasi dari kedua faktor tersebut yang mendorongnya.Proses pergeseran mata pencaharian masyarakat Desa Tangki Dahuyan dari sektor pertambangan dan pertanian ke perkebunan. Setiap masyarakat mengalami perubahan.Perubahan tidak berjalan secara tiba-tiba, namun mempunyai gejala atau tahapan-tahapan sebelum mengalami perubahan (Saefulloh, 2019). Setiap Desa punya kecenderungan untuk bergerak menuju pola kota. Pergeseran dapat terjadi karena direncanakan secara sistematis, namun juga dapat terjadi tanpa terkontrol atau tidak terencana terlebih dahulu.Pergeseran yang terjadi di Desa Tangki Dahuyan tidak direncanakan oleh pembuat kebijakan yang menentukan arah dari perubahan yang dituju. Perubahan apapun bentuknya akan meninggalkan bentuk yang diubah dan akan berjalan menuju kepada bentuk yang baru yang diharapkan (meskipun tidak direncanakan tapi perubahan biasa diharapkan).

\section{Paris Langkis}

Vol.1 No. 1, Agustus 2020 


\section{METODE PENELITIAN}

Metode penelitian menggunakan metode deskristif kualitatif. Subjek penelitian ini adalah kepala desa, masyarakat Desa Tangki Dahuyan seperti peyedap karet dalam hal yang ditanya sebagai informan tentang pergeseran mata pencaharian masyrakat. Prosedur pegumpulan data menggunakan observasi partisipatif, wawancara mendalam dan dokumentasi sedangkan analisis data meliputi reduksi data, display data, dan verifikasi data dan pemeriksaan keabashan data melalui triangulasi teknik dan triangulasi sumber.

\section{HASIL DAN PEMBAHASAN}

Demikian juga halnya dengan Desa Tangki Dahuyan, Kecamatan Manuhing, Kabupaten Gunung Mas yang merupakan salah satu Desa dimana mayoritas penduduknya bermata pencaharian pada sektor pertanian dan petani karet serta penambang emas.Pada mulanya hampir semua bahkan atau mayoritas warganya mempunyai pekerjaan pokok atau bermata pencaharian sebagai petani.Sebagaimana yang dikemukan oleh Bapak Eli mengenai proses awal terjadinya pergeseran mata pencaharian pada masyarakat Desa Tangki Dahuyan bahwa : "proses terjadinya pergeseran yaitu dulunya masyarakat Desa Tangki Dahuyan bekerja mayoritas sebagai petani dan menyadap karet serta menambang emas dilokasi masing-masing bagi yang mempunyai lahan tanah, kemudian seiring berjalannya waktu sekitar tahun 2009 selain turun naiknya harga hasil alam, dan bukanya perusahaan kelapa sawit, maka sedikit demi sedikit masyarakat disini mulai mendaftarkan diri ke perusahaan untuk bekerja menjadi karyawan hingga sampai sekarang dengan berbagai jabatan mulai dari menanam, memupuk, membersihkan, memetik hingga menjadi mandor diperusahaan"(Wawancara, 28 April 2019)

Pendapat di atas juga dikemukakan oleh Ibu Sini bahwa "Yang melatarbelakangi pergeseran pekerjaan di Desa Tangki Dahuyan ini sepengetahuan saya untuk merubah nasib dan usaha dalam bidang ekonomi, dikarenakansulitnya pekerjaan yang ada di Desa Tangki Dahuyan dan menurunnya harga-harga karet dan hasil petani di ladang sehingga kebanyakan warga disini memilih untuk ikut bekerja di perusahaan kelapa sawit".(Wawancara, 30 April 2019)

Pergeseran mata pencaharian secara umum adalah hal yang wajar dilakukan dibeberapa kalangan masyarakat seiring dengan perubahan serta perkembangan jaman yang dilalui. Berbicara perubahan jaman dan kemajuan maka secara tidak langsung juga akan mempengaruhi kebutuhan hidup masyarakat, terutama pada masyarakat dari kalangan bawah hingga menengah. Semakin tingginya kebutuhan juga memaksa masyarakat untuk meninggalkan pekerjaan lama seperti halnya pada masyarakat Desa Tangki Dahuyan yang juga mengalami pergeseran mata pencaharian.

Pergeseran yang terjadi pada masyarakat tersebut bukan hanya faktor perkembangan jaman dan perubahan jaman namun lebih disebabkan karena rasa yang ingin lebih maju, perubahan nasib serta perubahan ekonomi yang lebih baik agar terlepas dari zona kemiskinan jika bertahan dengan pekerjaan lamanya. Terlebih hasil alam yang saat ini kian menurun, menurunnya harga karet, banyaknya kegagalan dalam panen padi serta terbatasnya hasil alam ataupun hasil penambangan emas, sehingga membuat masyarakat Desa Tangki Dahuyan selain memanfaatkan kesempatan kerja juga menopang kehidupan dengan meninggalkan pekerjaan lama ke pekerjaan baru yaitu menjadi karyawan di perusahaan sawit sekitar Desa Tangki Dahuyan. Pergeseran mata pencaharian yang terjadi pada masyarakat Desa Tangki Dahuyan yang telah peneliti lakukan dan berdasarkan hasil dilapangan yang didapat disebabkan oleh beberapa faktor seperti menurunnya

\section{Paris Langkis}

Vol.1 No. 1, Agustus 2020 
hasil alam serta masyarakat lebih memilih menjadi karyawan perusahaan sawit karena hasil dan gaji yang diterima lebih besar dibanding jika bertahan dengan pekerjaan lama.

Penyebab pergeseran mata pencaharian tersebut sejalan dengan teori yang dikemukakan oleh Soerjono Soekanto, (2007: 275-282) yang mengatakan bahwa :

a. Bertambah atau berkurangnya penduduk.

b. Penemuan-penemuan baru

c. Pertentangan (conflict) masyarakat

d. Terjadinya pemberontakan atau revolusi

e. Sebab-sebab yang berasal dari lingkungan alam fisik yang ada di sekitar manusia.

f. Peperangan

g. Pengaruh kebudayaan masyarakat lain.

h. Rasa ingin lebih maju

Teori di atas jelas bahwa terjadinya suatu pergeseran pada masyarakat disebabkan beberapa faktor mulai dari pertambahan penduduk atau berkurangnya suatu penduduk di daerah tersebut, kemudian penemuan baru seperti adanya atau masuknya perusahaan kelapa sawit pada daerah Desa Tangki Dahuyan.Lingkungan fisik alam yang sudah tidak bersabat dengan masyarakat seperti kurangnya hasil alam yang ada di Desa Tangki Dahuyan seperti turunnya harga karet, cuaca yang tidak menentu serta hasil sawah yang tidak lagi dapat memberikan hasil yang sesuai dengan harapan masyarakat desa serta rasa ingin lebih maju yang dirasakan masyarakat Desa Tangki Dahuyan jika terus menerus bertahan dengan pekerjaan lama maka tidak akan ada perubahan hidup, terbukti saat sekarang masyarakat yang telah melakukan pergeseran mata pencaharian sudah dapat lebih maju dengan hasil beberapa tahun berkerja menjadi karyawan perusahaan sudah dapat merenovasi rumah, membeli kendaraan dan hingga mampu menyekolahkan anakanaknya ke jenjanng perguruan tinggi hingga ada yang pergi ke luar Kalimantan. Dengan demikian bahwa pergeseran dilakukan dengan adanya beberapa faktor di atas tersebut.

Pergeseran mata pencaharian atau biasa disebut transformasi pekerjaan adalah pergeseran atau perubahan dalam pekerjaan pokok yang dilakukan manusia untukmhidup dan sumber daya yang tersedia untuk membangun kehidupan yang memuaskan (peningkatan taraf hidup) dengan memperhatikan faktor seperti mengawasi penggunaan sumber daya, lembaga dan hubungan politik.Perubahan mata pencaharian ini ditandain dengan adanya perubahan orientasi masyarakat mengenai mata pencaharian.Mata pencaharian masyarakat di Indonesia pada umumnya berasal dari sektor agraris.

Perubahan orientasi mata pencaharian disini diartikan sebagai perubahan pemikiran masyarakat yang akan menentukan dan mempengaruhi tindakannya di kemudian hari, dari pekerjaan pokok masyarakat yang dahulunya di sektor agraris bergeser atau berubah ke sektor nonagraris. Hal ini melihat konstruk pemikiran (ide) yang menurut Hegel menentukan tindakan manusia.Meskipun dalam taraf konstruk pemikiran gejala pergeseran atau perubahan tersebut sudah terjadi dalam realitas di masyarakat (Fajar Hatma, 2003:37).

Pergeseran mata pencaharian dari sektor agraris ke sektor non-agraris,yang dapat dijelaskan bahwa mata pencaharian sektor agraris adalah pekerjaan pokok yang berhubungan dengan perkebunan lada, baik secara langsung ataupun secara tidak langsung. Sedangkan untuk mata pencaharian sektor non-agraris adalah pekerjaan pokok yang berhubungan dengan pertambangan inkonvensional baik itu yang berijin ataupun yang tidak memiliki ijin, baik secara langsung

\section{Paris Langkis}

Vol.1 No. 1, Agustus 2020 
ataupun secara tidak langsung. Mata pencaharian sendiri dapat didefinisikan sebagai pekerjaan pokok yang dilakukan oleh masyarakat.

\section{E. KESIMPULAN}

Perubahan mata pencaharian atau biasa disebut transformasi pekerjaan adalah pergeseran atau perubahan dalam hal mata pencaharian.Pergeseran mata pencaharian ini juga dilakukan oleh masyarakat Desa Tangki Dahuyan, Kecamatan Manuhing, Kabupaten Gunung Mas.Pergeseran mata pencaharian dari penyadap karet dan petani sebagai pergeseran suatu mata pencaharian. Setiap perubahan sosial atau fenomena sosial terjadi pada saat dan waktu tertentu dan melalui proses atau tahapan-tahapan tertent. Demikian juga halnya yang terjadi pada pergeseran mata pencaharian masyarakat Desa Tangki Dahuyan.proses terjadinya pergeseran mata pencaharian pada masyarakat Desa Tangki Dahuyan.

1. Faktor penyebab dan pendorong pergeseran mata pencaharian masyarakat Desa Tangki Dahuyan terbagi menjadi dua faktor internal dan eksternal. Faktor internal yaitu rasa ingin merubah nasib menjadi lebih baik dengan meningkatnya suatu hasil pendapatan dengan harapan ekonomi keluarga lebih membaik disbanding sebelumnya. Faktor eksternal yaitu suatu faktor dari luar seperti dorongan ingin menjadi lebih maju, pendapatan yang pasti setiap bulan, menyekolahkan anak-anaknya agar kelak meraih sukses melalui pendidikan dan tidak terpuruk dalam keadaan seperti orang tuanya. Selain itu juga meningkatnya pengahasilan keluarga dan mendapatkannya suatu jaminan sosial seperti Jaminan Sosial Tenaga Kerja (JAMSOSTEK) dan BPJS Kesehatan.Pemerintah dalam hal ini Pemda maupun pihak-pihak terkait lainnya sebaiknya dapat lebih memperhatikan masyarakat dengan tetap menjaga kestabilan harga karet yang dulunya merupakan suatu mata pencaharian masyarakat.

2. Kepada masyarakat Desa Tangki Dahuyansebaiknya tidak mudah tergiur dan tidak menjual semua lahan atau kebun yang dimiliki kepada pihak perusahaan serta jangan terlena dengan yang sudah ada saat ini, tetapi mari berpikir lebih jauh untuk masa depan anak cucu ke depan karena

\section{REFERENSI}

Angkasawati. (2015). Masyarakat Desa. Jurnal Publiciana.

Eko Murdiyanto. 2008. Sosiologi Pedesaan Pengantar Untuk Memahami Masyarakat Desa. Yogyakarta: Wisma Press "UPN Veteran"

Ismanto, K., Huda, M., \& Maulida, C. (2013). TRANSFORMASI MASYARAKAT PETANI MRANGGEN MENUJU MASYARAKAT INDUSTRI. JURNAL PENELITIAN. https://doi.org/10.28918/jupe.v9i1.129

Jaya, Pajar Hatma Indra. 2003. Transformasi Tenaga Kerja Pedesaan, Surakarta, Skripsi

Mulyawan, R (2006). Perubahan Orientasi Mata Pencaharian Pada Masyarakat Desa. Skripsi : Jurusan Pendidikan UPI.

Rolina, L. O. (2013). ORIENTASI PERUBAHAN MATA PENCAHARIAN PETANI DI KECAMATAN PARONGPONG KABUPATEN BANDUNG BARAT. Jurnal Antologi Geografi.

\section{Paris Langkis}


Saefulloh, F. S. (2019). Kolaborasi yang Dilaksanakan di Kawasan Wisata Dermaga Kereng Bangkirai Kota Palangka Raya. Jurnal Administrasio , 71-80.

Sugiyono 2013. Metode Penelitian Pendidikan Pendekatan Kuantitatif, Kualitatif, dan R E D. Alpabeta Bandung.: FISIP UNS.

Sutyitno, I. (2012). The development of education on the character and culture of the nation based on the local wisdom. Jurnal Pendidikan Karakter. 